\title{
Farklı Organik Gübrelerin Tohumluk Patates (Solanum tuberosum L.) Çeşitlerinde Verim ve Kalite Üzerine Etkileri
}

\author{
Hasan Eleroğlu ${ }^{*}$, Kürşat Korkmaz ${ }^{2}$ \\ 1Cumhuriyet Üniversitesi, Şarkışla A.V. Meslek Yüksekokulu, 58400 Şarkışla/Sivas, Türkiye \\ ${ }^{2}$ Ordu Üniversitesi, Ziraat Fakültesi, Toprak Bilimi ve Bitki Besleme Bölümü, 52200 Ordu, Türkiye
}

M A K A L E B İ L G İ S İ

Geliş 26 Mart 2016

Kabul 25 Temmuz 2016

Çevrimiçi baskı, ISSN: 2148-127X

\section{Anahtar Kelimeler:}

Kompost

Fermente

Organomineral

Tavuk gübresi

Organik gübreleme
Ö Z E T

$\mathrm{Bu}$ çalışma, organomineral gübre ve tavuk gübresi kullanımının farklı patates (Solanum tuberosum L.) çeşitlerinin tohumluk yumrularında verim ve kalite üzerine etkilerini belirlemek amacıyla yapılmıştır. Araştırmada, Hexaferm organomineral gübresi (\%20 organik madde, 8-21-0+Zn), kompost (1 t da-1) ve fermente tavuk gübresi (1 t da-1) olmak üzere 3 farklı gübre uygulaması ile 8 farklı patates çeşidi (Madaline, Provento, Marfona, Agata, Arizona, Mustang, Rumba ve Saviola) tesadüf bloklarında faktöriyel deneme desenine göre 3 tekerrürlü olarak çalışılmıştır. Gübre formlarının, farklı patates çeşitlerindeki verim ve kalite özellikleri üzerine etkisini belirlemek amacıyla yumruların çıkış süreleri, çıkış oranları, bitki boyu, ana sap sayısı, ocak başına yumru verimi, toplam yumru verimi, çatlak yumru verimi, kuru madde içeriği, nişasta içeriği ve özgül ağırlığı incelenmiştir. Kullanılan gübreler çeşitlerin ortalama çıkış süresi, çıkış oranı, bitki boyu, ana sap sayısı, toplam yumru verimi, çatlak yumru verimi, kuru madde içeriği, nişasta içeriği ve özgül ağırlı̆̆ı üzerine önemli bir etkide bulunmamıştır . Çeşitlerin çıkış süresi, çıkış oranı, bitki boyu, ana sap sayısı, arasında gözlenen farklılık önemsiz olarak hesaplanmıştır . Çeşitlerin ortalama ocak başına yumru verimi, toplam yumru verimi, çatlak yumru verimi, kuru madde içeriği, nişasta içeriği ve özgül ağırlık ortalamaları arasındaki fark önemli bulunmuştur . Benzer şekilde, kullanılan gübreler çeşitlerin ocak başına verimleri üzerine önemli etki göstermiştir . Ortalama ocak başına yumru verimi ve özgül ağırlık ortalamaları bakımından önemli Gübre x Çeşit interaksiyonu bulunmuştur. Sonuç olarak, ekonomik açıdan değerlendirildiğinde patates üretiminde kompost veya fermente tavuk gübrelerinin organomineral gübre uygulamaları yerine kullanılabilir.

Turkish Journal Of Agriculture - Food Science And Technology, 4(7): 566-578, 2016

\section{Effects of Different Organic Fertilizers on the Yield and Quality Traits of Seed Potato Cultivars (Solanum} Tuberosum L.)

\section{A R T I C L E IN F O}

Article history:

Received 26 March 2016

Accepted 25 July 2016

Available online, ISSN: 2148-127X

\section{Keywords:}

Compost

Fermented

Organo-mineral

Poultry manure

Organic Fertilization

*Corresponding Author:

E-mail: eleroglu@cumhuriyet.edu.tr

\section{A B S T R A C T}

This study was conducted to determine the effects of use organo-mineral fertilizers and poultry manure on yield and quality of seed tubers different potatoes varieties (Solanum tuberosum L.). The study was designed in three replicated completely randomized block factorial design with eight potato cultivars (Madaline, Provento, Marfona, Agata, Arizona, Mustang, Rumba and Saviola) and including three different fertilizer as Hexaferm organo-mineral (\%20 organics, 8-21-0+Zn), compost $\left(1 \mathrm{t} \mathrm{da}^{-1}\right)$ and fermented poultry manure $\left(1 \mathrm{t} \mathrm{da}^{-1}\right)$. In order to determine the effect of fertilizer forms on the yield and quality characteristics of different varieties of potatoes were examined features like output time of the tuber, output rates, plant height, stem number per hill, tuber yield per hill, total tuber yield, cracks tuber yield, dry matter content, starch content and specific gravity. Used fertilizers have no significant effect on output time of the tuber, output rates, plant height, stem number per hill, total tuber yield, dry matter content, starch content and specific gravity of varieties. The difference observed in terms of output time of the tuber, output rates, plant height, stem number per hill between the varieties was insignificant. The difference between the average tuber yield per hill, total tuber yield, cracks tuber yield, dry matter content, starch content and specific gravity of varieties were significant. Similarly, the fertilizers had a significant effect on the average tuber yield per hill of varieties. The significant interactions were found on traits average tuber yield per hill and average specific gravity between Fertilizer x Varieties. As a result, considered economically the fermented and compost poultry manure can be used instead of organo-mineral fertilizers in the production of seed potatoes. 


\section{Giriş}

Yirminci yüzyılın başından itibaren yoğun olarak kullanılan suni gübre, büyüme düzenleyiciler ve zirai ilaçlar, toprak, su, hava, gıda; dolayısıyla canlı kalitesini bozmuştur. $\mathrm{Bu}$ girdilerin ortaya çıkardığı olumsuz etkiler ilk önce yoğun olarak kullanıldığı gelişmiş ülkelerde görülmüş, buna bağlı olarak yirminci yüzyılın başlarında geliştirilen alternatif teknikleri irdeleme arayışları başlamıştır. Tekrar eski kaliteye ulaşmak için çevreye dost faktörlerin bir şekilde kullanılması gündeme gelmiştir. Böylece birçok ülkede konvansiyonel tarımdan organik tarıma geçilmeye başlanmıştır (Genç, 2006; Zengin, 2007).

Artan insan nüfusuyla birlikte büyüyen hayvancılık endüstrisi, hem gelişmiş hem de gelişmekte olan ülkelerde çevresel sorunlar oluşturan yüksek miktarlarda hayvansal atığın oluşmasına neden olmaktadır. Türkiye'de, son yıllarda özellikle kümes ve çiftlik hayvanlarından kaynaklanan hayvansal atıklar, en önemli ve en ciddi çevresel problemler arasında yer almaktadır. Bu nedenle tavukçuluk sektöründe dişkının oluşturduğu çevresel sorunlar önem kazanmaktadır (Koç, 2002; Eleroğlu ve Yildırım, 2011).

Hayvancılık işletmelerinde çevre sorunlarına neden olan atıklar, aynı zamanda önemli bir ekonomik potansiyeldir. Hayvansal kaynaklı atıkların çoğunun gübre ve yem üretimi gibi alanlarda kullanımı olasıdır. $\mathrm{Bu}$ nedenle hayvancılığa bağlı atıkların değerlendirilmesi çevre baskısını azaltacak, atıl durumda bulunan ekonomik kaynak değerlendirilmiş olacaktır (Karaman, 2006). Ancak bu atıkların herhangi bir yönetime tabi tutulmadan bilinçsizce ekim alanlarına, meralara, açık alanlara ve akarsulara atılması, ürün çeşitliliğini ve kalitesini düşürmekte ve toprağın biyolojik yapısını tahrip ederek faydalı kullanım özelliklerini bozabilmektedir (Yetilmezsoy, 2010).

Tarımda organik gübre sıkıntısı çekilirken kafes sistemiyle tavukçuluk yapılan işletmelerde sulu tavuk gübresinin depolardan çevreye taşması ve pis koku nedeniyle önemli çevre problemi oluşturması bir çelişki örneğidir. $\mathrm{Bu}$ nedenle sulu tavuk gübresinin çevreyi kirleten ve sağlık bozan bir konumdan çıkarılması, organik gübreye dönüştürülmesi ve tarıma kazandırılması gerekmektedir (Korkmaz ve ark., 1996; 2000).

Organik artıkların dünya genelinde gübre olarak kullanımı geçmiş yüzyıllarda olduğu gibi son yıllarda da giderek yaygınlaşmakta, toprağın kimyasal yapısı ve ürün verimi üzerine potansiyel etkilerini değerlendirmek üzere yapılacak çalışmalara gereksinim duyulmaktadır (Dikinya ve Mufwanzala, 2010). Ayrıca tavuk gübresi, içerdiği yüksek azot, fosfor ve potasyum miktarı nedeniyle diğer hayvansal gübrelerin kullanımından daha önemli hale gelmiştir. Artan akaryakıt fiyatları, inorganik gübre fiyatlarının artmasına dolaylı etkide bulunmakta dolaysıyla tavuk gübresinin kullanımının artmasına neden olmaktadır. Diğer taraftan dünya genelinde birçok çevre kuruluşları sürdürülebilir tarım için organik gübre uygulamasını önermektedir.

Tavukçuluk katı atıkları değișen miktarlarda su, bitki besleme açısından önemli azot, fosfor, potasyum, kalsiyum, magnezyum, kükürt, manganez, bakır, çinko, klor, bor, demir ve molibden gibi mineral besin maddeleri ve organik madde içermektedir (Edwards ve Daniel,
1992; Brady ve Weil, 1996; Amanullah ve ark., 2010).

İçerdiği yüksek makro besin maddeleri bakımından diğer hayvansal atıklara oranla tavuk dışkısı daha fazla tercih edilmektedir. Chescheir ve ark. (1986), üzerinde çalıştıkları topraklarda tavuk gübresinin azot düzeyini yükselttiğini bildirmektedirler. Yapılan birçok çalışmada olduğu gibi Dikinya ve Mufwanzala (2010), toprağın azot ve fosfor düzeyi üzerine olumlu etkisini saptadıkları bir çalışmada, ürün verimi üzerine de olumlu etkilerini belirlemekte ve tavuk gübresini önemli bir bitki besin maddesi olarak değerlendirmektedirler.

Patates üretiminde karşılașilan sorunlar arasında kimyasal gübre kullanımı ilk sırada yer almaktadır (Şahin, 2003). Nitekim patatesin yumrusu ve vejetatif gelişimi için gerekli olan besin elementleri miktarı oldukça fazla olup, 1 ton yumru üretimi için $8,0 \mathrm{~kg} / \mathrm{da}$ potasyum, 5,4 $\mathrm{kg} / \mathrm{da}$ azot ve $1,4 \mathrm{~kg} / \mathrm{da}$ fosfora ihtiyaç duymaktadır (Er ve Uranbey, 1998). Bitki besin elementi ihtiyacinı karşılamak için kullanılan suni gübreler ise bir yandan patatesin üretimine katkı sağlarken, diğer taraftan suyu ve toprağ 1 kirletmektedir (Ekin ve ark., 2013). Farklı iklim bölgelerinde yetiştirilebilen patates bitkisine ülkemizde fazla miktarda gübre verilmektedir. Gereğinden fazla yapılan gübreleme büyük ekonomik kayılara sebep olmaktadır (Karadoğan, 1996).

Hsieh ve ark. (1994), tatlı biberin yetişmesi ve verimi üzerine organik gübrelerin etkisini belirlemek amacıyla yaptıkları çalışmada kimyasal gübre olarak $150 \mathrm{~kg} \mathrm{~N}+120$ $\mathrm{kg} \mathrm{P}_{2} \mathrm{O}_{5}+150 \mathrm{~kg} \mathrm{~K}_{2} \mathrm{O}$ ha $^{-1}$ ve buna eşdeğer oranda organik gübreler (tavuk gübresi, domuz gübresi, fermente edilmiş atık yağ, pirinç kabuğu, pirinç samanı) uygulamışlardır. Uygulanan kimyasal gübrelere oranla organik gübreler bitki yüksekliği, meyve miktarı, meyve büyüklüğü, meyve sayısı ve verimi önemli seviyede artırmıştır. Bununla beraber organik gübreler meyvedeki Fe ve $\mathrm{Mn}$ oranlarını düşürmüştür.

Kütük ve Topçuoğlu (1997), yaptıkları tarla denemesinde toprağa değişik oranlarda uygulanan organik gübrelerle (koyun, sığır ve tavuk gübreleri) ticari amonyum nitrat gübresinin ispanak bitkisinde toplam ve suda çözünebilir oksalik asit, kalsiyum, toplam azot ve organik bağlı azot içerikleri üzerine etkilerini incelemişlerdir. Araştırma sonucunda, amonyum nitrat gübresinin toprağın sadece toplam azot içeriği ile $\mathrm{NH}_{4}-\mathrm{N}$ ve ${ }_{\text {NO3 }}$-N'u içeriklerini artırdığını buna karşın uygulanan organik gübrelerin organik madde ve toplam azot başta olmak üzere toprağın $\mathrm{NH}_{4}-\mathrm{N}$ ve $\mathrm{NO}_{3}-\mathrm{N}$, toplam $\mathrm{P}$, toplam $\mathrm{K}$ ve $\mathrm{Ca}$ içeriğini yükselttiğini saptamışlardır.

Kara ve Erel (1999), laboratuvar şartlarında tavuk gübresinin toprağa uygulanmasıyla, toprağın bazı özellikleri ile yulaf bitkisinin verimine olan etkisini araştırmışlardır. Farklı dozlarda tavuk gübresi uygulanarak 84 gün inkübasyona bırakılan topraklarda $\mathrm{pH}$ ve suda çözünebilir toplam tuz ile $\mathrm{Fe}, \mathrm{Cu}, \mathrm{Zn}, \mathrm{Mn}$ içerikleri tayin edilmiştir. Araştırma sonucuna göre, artan tavuk gübresi dozlarına bağlı olarak, toprakların suda çözünebilir toplam tuz, Fe ve Zn içeriğinin arttığını, buna karşılık toprak pH'sı ve $\mathrm{Cu}$ içeriğinin azaldığı $\mathrm{Mn}$ içeriğinin ise değişmediğini tespit etmişlerdir. Ayrıca tavuk gübresinin yulafın kuru bitki ağırlığını artırdığını saptamışlardır. 
Şeker ve Ersoy (2005), sera şartlarında çöp kompostu, sığır gübresi, tavuk gübresi ve leonarditin farklı dozlarının toprak özellikleri ve mısır bitkisinin gelişimine etkilerini araştırmışlardır. Araştırma sonucunda kullanılan organik gübrenin çeşidi ve dozlarının toprak özellikleri ile mısırın gelişimini etkilediğini saptamışlardır. Mısır bitkisinin verim unsurları ile boy uzunluğu üzerine en fazla etkiyi tavuk gübresi yapmıştır.

Tavuk dişkısının atık olarak işlenmesinde aerobik ve anaerobik işlemler, kompostlama, yakma gibi yöntemlerin yanı sıra son y1llarda farklı kurutma teknikleri de kullanılmaktadır. Tavuk dışkısının organik gübre olarak kullanılması, onu çevre sorunu yaratan atık olmaktan çıkaracak ve tarımda kullanılmasıyla üretimde katkısı artacaktır. Bu nedenle, tavuk dışkısından gübre üretmeye yönelik teknolojilerin geliştirilmesine gereksinimler bulunmaktadır (Eleroğlu ve ark., 2013).

$\mathrm{Bu}$ çalışma, organomineral gübre ve tavuk gübresi kullanımının farklı patates (Solanum tuberosum L.) çeşitlerinin tohumluk yumrularında verim ve kalite üzerine etkilerini belirlemek amacıyla yapılmıştır.

\section{Materyal ve Yöntem}

\section{Materyal}

Cumhuriyet Üniversitesi yerleşkesi içerisinde 1261 rakımda Kızılırmak kenarında bulunan daha önce hiçbir şekilde patates tarımı yapılmamış arazi 2013 yılında tohumluk patates üretimi için araştırma sahası olarak kullanılmıştır. Denemenin yapıldığı toprak killi-tınlı, tuz oranı \% 0,045 (tuzsuz), pH 8,1 (alkalin), kireç oranı $\% 10,1$ (orta kireçli), fosfor miktarı 9,6 kg/da (yeterli), potasyum miktarı 180,5 $\mathrm{kg} / \mathrm{da}$ (zengin), organik madde içeriği \% 1,4 (az) olarak saptanmıştır.

Çeşit olarak yurt dişından (Hollanda) ithal edilen Madaline, Provento, Marfona, Agata, Arizona, Mustang, Rumba ve Saviola çeşitlerinin anaç tohumluk sınıfindaki yumruları, gübre olarak ise organomineral gübre ile fermente ve kompost yöntemleriyle elde edilmiş olan tavuk gübreleri araştırmada kullanılmıştır. Organomineral gübrenin yapısı, kullanılma şekli ile fermente ve tavuk gübresinin kimyasal yapısı ile kullanım miktarları Tablo 1 'de verilmiştir.

\section{Yöntem}

Araştırma ile ilgili tarla denemesi (Tablo 2) tesadüf bloklarında faktöriyel deneme deseninde $(8 \times 3 \times 3) \quad 3$ tekerrürlü olarak ana ürün koşullarında, Cumhuriyet Üniversitesi yerleşkesi içinde yer alan tarıma uygun 504 $\mathrm{m}^{2}$ alanda yürütülmüştür. Her parsel $2,5 \mathrm{~m}$ uzunluğunda $70 \mathrm{~cm}$ sıra aralıklı 4 ekim sırasından oluşmuştur $(2,8 \mathrm{~m} \mathrm{x}$ $2,5 \mathrm{~m}=7 \mathrm{~m}^{2}$ ). Parseller arasinda $70 \mathrm{~cm}$, bloklar arasinda ise $1 \mathrm{~m}$ mesafe bırakılmıştır. Uygulamalar parsellere rastgele dağıtılmışlardır. Denemede sıra üzeri $20 \mathrm{~cm}$ aralık olacak şekilde dikim yapılmış, bütün gözlem, ölçüm ve değerlendirmelere dair veriler kenarlardaki 2 sıra atıldıktan ve ortadaki 2 sıranın da baş ve sonlarından birer ocak kenar etkisi birakıldıktan sonra geriye kalan kısımlardan alınmıştır.

Tohumluk patates üretimine uygun toprak hazırlığ yapıldıktan sonra 70x20 cm siklıkta elle dikim yapılmıştır. Tüm çeşitlerin hasadı makineli olarak yapılmıştır.

Tablo 1 Araştırmada kullanılan gübrelerin kimyasal yapıları

\begin{tabular}{l|ccc}
\hline Özellikler & Organomineral $(\%)$ & Granül Kompost TG(\%) & Pelet Fermente TG(\%) \\
\hline Toplam organik madde & 20 & 35 & 55 \\
Toplam azot & 8 & 3,5 & 2 \\
Organik azot & 0,2 & 0,3 & 1 \\
Amonyum azotu & 7,8 & & 3 \\
Toplam $\mathrm{P}_{2} \mathrm{O}_{5}$ & 21 & 0,5 & \\
Suda çözünür $\mathrm{P}_{2} \mathrm{O}_{5}$ & 14 & & \\
Suda çözünür $\mathrm{K}_{2} \mathrm{O}$ & 0 & & \\
Toplam $(\mathrm{Hümik}+$ Fülvik) & 7 & & \\
Toplam $\mathrm{SO}_{3}$ & 5 & & 20 \\
Toplam çinko $(\mathrm{Zn})$ & 0,1 & & $6-8$ \\
Maksimum nem & 16,6 & & \\
pH & 7,2 & & \\
\hline
\end{tabular}

Tablo 2 Deneme deseni

\begin{tabular}{l|cccc}
\hline \multirow{2}{*}{ Çeşitler } & \multicolumn{3}{c}{ Gübre uygulamaları } & \multirow{2}{*}{ Çeşit Parsel Sayısı } \\
\cline { 2 - 5 } & Organomineral & Kompost & Fermente & 9 \\
Madaline & 3 & 3 & 3 & 9 \\
Provento & 3 & 3 & 3 & 9 \\
Marfona & 3 & 3 & 3 & 9 \\
Agata & 3 & 3 & 3 & 9 \\
Arizona & 3 & 3 & 3 & 9 \\
Mustang & 3 & 3 & 3 & 9 \\
Rumba & 3 & 3 & 3 & 9 \\
Saviola & 3 & 3 & 24 & 72 \\
Gübre parsel sayıs1 & 24 & 24 & & \\
\hline
\end{tabular}


Taban gübresi olarak seçilen organomineralin kullanım dozu $100 \mathrm{~kg} /$ dekar olmasına karşın kompost ve fermente tavuk gübrelerinin kullanım dozu eşit olarak $1000 \mathrm{~kg} / \mathrm{dekar}$ olarak uygulanmıştır. Araştırmada kullanılan tavuk gübresi formlarının çeşitlerin verim ve kalite özellikleri üzerine etkisini belirlemek amacıyla aşağıda verilen belirlemeler yapılmıştır (Esendal, 1990; Yllmaz, 1993).

Çıkış süresi (gün): Dikim tarihi ile, parsellerdeki ocakların \%50'den fazlası toprak yüzeyine çıktığı tarih arasındaki süre gün olarak belirlenmiștir.

Bitki boyu $(\mathrm{cm})$ : Parsellerde tesadüfen belirlenen 24 bitkinin tam çiçeklenme döneminde (boyca uzama durduğunda), toprak seviyesiyle bitkinin en üst kısmı arasındaki mesafe ölçülerek ortalaması alınmıştır.

Ana sap saylsi/ocak (adet): Parsellerde tesadüfen belirlenen 24 bitkide, topraktan doğrudan çıkış yapan ana sapların oluşumu tamamlandığında, ana sap sayıları belirlenerek ortalamaları alınmıştır.

Ocak başına yumru verimi (g/ocak): Parsellerin net alanlarından hasat edilecek olan toplam yumru verimi, o parseldeki ocak sayısına bölünerek gram cinsinden ifade edilmiştir.

Yumru saylsl/ocak: Her bir parseldeki yumrular (1skartalar ayrıldıktan sonra) sayılıp, o parseldeki ocak sayısına bölünerek belirlenmiștir.

Ortalama yumru ăgırlığl/ocak (g): Her bir parsele ait ocak başına yumru verimi, o parseldeki ocak başına yumru sayısına bölünerek, belirlenmiştir.

Toplam yumru verimi $(\mathrm{kg} / \mathrm{da})$ : Her bir parselden alınan yumru miktarı, o parselin alanı üzerinden hesaplanarak, dekara dönüştürülmüştür.

Çatlak yumru verimi (\%):Her parselden hasat edilen yumrular içerisinde çatlak olanların sayısı belirlenmiș ve toplam yumru sayısına oranlanmıştır.

Kuru madde ve nişasta oranı (\%): Kuru madde oranları Arşimet yöntemine göre özgül ağıllık esasına dayalı olarak belirlenerek, kuru madde ve nişastaya dönüşümleri yapılmıştır.

Tesadüf bloklarında faktöriyel deneme deseninde yürütülen bu araştırmada istatistiksel analizler ve gruplara ait parametrelerinin ortalamaları arasındaki önemliliğgin tespiti için gübre ve çeşit, ve bunların interaksiyon etkilerini de içerecek şekilde varyans analiz metodu (SPSS 16.0 Inc. Chicago. IL. USA) uygulanmıştır.

\section{Bulgular}

Verim ve kalite değerlerini belirlemek üzere Yumruların çıkış süreleri, Çıkış oranları, Bitkilerin boyu, Bitkilerin ana sap sayısı, Ocak başına yumru verimi, Toplam yumru verimi, Çatlak yumru verimi, Kuru madde içeriği, Nişasta içeriği ve Özgül ağırlık özelliklere ilişkin veriler toplanarak analiz edilmiştir.

Yumruların çıklş süreleri: Dikim ile birlikte parsellerde ocakların \%50'den fazlası toprak yüzeyine çıktığ 1 tarih arasındaki süre çıkış için geçen süre olarak kaydedilmiştir. Elde edilen verilerde istatistik analiz sonucunda elde edilen bulgular Tablo 3 verilmiştir.

Taban gübresi olarak Organomineral, kompost ve fermente tavuk gübresi kullanımının denemede kullanılan çeşitlerin çıkış süreleri üzerine farklı bir etkisi bulunmamıştır $(\mathrm{P}>0,05)$. Çeşitlerin çıkış süreleri arasında gözlenen farkl11lk önemsiz olup ( $\mathrm{P}>0,05)$, Gübre $\mathrm{x}$ Çeşit interaksiyonuna da rastlanmamıştır $(P>0,05)$. Çeşit ve gübre uygulamalarından elde edilen ortalama çıkış sürelerinin ortalaması 26,70 gün Sivas koşullarında kullanılan çeșitlerin çıkıs süresi olarak belirlenebilir.

Gübre $\mathrm{x}$ Çeşit interaksiyonu önemsiz $(\mathrm{P}>0,05)$ olarak hesaplanmıştır.

Yumruların çıklş oranları: Araştırma parsellerinde dikimi yapılan her yumrudan çıkanların sayıları belirlenerek çıkış oranları belirlenmiş, verilerin varyans analizi sonuçları Tablo 4 özetlemiştir. Ortalama çıkış oranları dikkate alındığında, kullanılan gübre formlarının çıkış oranı üzerine olumsuz bir etkisinin bulunmadığı $(\mathrm{P}>0,05)$, benzer şekilde Organomineral, kompost ve fermente tavuk gübrelerinin çeşitlerin çıkış oranlarında farklılığa neden olmadığı görülmektedir $(\mathrm{P}>0,05)$.

Çeşitlerin çıkış oranları ortalamaları \%86,78 $\% 100,00$ arasında değişmektedir. Ortalamalar arasında önemli bir farklılık bulunmadığından genel olarak çıkış oranı $\% 96,30$ olarak hesaplanmıștır. Taban gübresi olarak kullanılan uygulamaların çeşitler üzerindeki etkisi \%5,50 - \%96,88 arasında değişmektedir. Benzer şekilde gübre uygulamaları bakımından önemli bir farklıl1k bulunmadığından genel çıkıș oranı \%96,30 olarak hesaplanmıştır. Gübre x Çeşit interaksiyonu önemsiz $(\mathrm{P}>0,05)$ olarak hesaplanmıştır.

Tablo 3 Uygulamalardan üretilen tohumluk yumruların çıkış süreleri (gün)

\begin{tabular}{|c|c|c|c|c|c|c|}
\hline \multirow{2}{*}{ Çeşitler } & \multicolumn{3}{|c|}{ Gübre uygulamaları } & \multirow{2}{*}{ Çeşit Ort. } & \multirow{2}{*}{$\mathrm{OSH}$} & \multirow{2}{*}{$\mathrm{P}$} \\
\hline & Organomineral & Kompost & Fermente & & & \\
\hline Madaline & 29,67 & 28,00 & 25,67 & 27,78 & 0,92 & ÖD \\
\hline Provento & 25,67 & 24,67 & 25,33 & 25,22 & 0,76 & ÖD \\
\hline Marfona & 26,33 & 26,33 & 25,33 & 26,00 & 0,67 & ÖD \\
\hline Agata & 27,33 & 24,00 & 28,33 & 26,56 & 1,17 & ÖD \\
\hline Arizona & 26,33 & 26,67 & 26,67 & 26,56 & 0,38 & ÖD \\
\hline Mustang & 27,00 & 26,00 & 28,00 & 27,00 & 0,47 & ÖD \\
\hline Rumba & 27,33 & 27,00 & 29,33 & 27,89 & 0,51 & ÖD \\
\hline Saviola & 25,67 & 26,33 & 27,67 & 26,56 & 0,56 & ÖD \\
\hline Gübre Ort. & 26,92 & 26,13 & 27,04 & & & \\
\hline $\mathrm{OSH}$ & 0,39 & 0,42 & 0,53 & & & \\
\hline $\mathrm{P}$ & ÖD & ÖD & ÖD & Gübre x Çeşit & & ÖD \\
\hline
\end{tabular}


Tablo 4 Uygulamalardan üretilen tohumluk yumruların çıkış oranları (\%)

\begin{tabular}{|c|c|c|c|c|c|c|}
\hline \multirow{2}{*}{ Çeşitler } & \multicolumn{3}{|c|}{ Gübre uygulamaları } & \multirow{2}{*}{ Çeşit Ort. } & \multirow{2}{*}{$\mathrm{OSH}$} & \multirow{2}{*}{$\mathrm{P}$} \\
\hline & Organomineral & Kompost & Fermente & & & \\
\hline Madaline & 100,00 & 100,00 & 100,00 & 100,00 & 0,00 & ÖD \\
\hline Provento & 100,00 & 90,33 & 100,00 & 96,78 & 3,22 & ÖD \\
\hline Marfona & 100,00 & 100,00 & 100,00 & 100,00 & 0,00 & ÖD \\
\hline Agata & 87,67 & 100,00 & 73,67 & 87,11 & 6,46 & ÖD \\
\hline Arizona & 100,00 & 100,00 & 100,00 & 100,00 & 0,00 & ÖD \\
\hline Mustang & 100,00 & 100,00 & 90,33 & 96,78 & 3,22 & ÖD \\
\hline Rumba & 84,67 & 84,67 & 100,00 & 89,78 & 6,76 & ÖD \\
\hline Saviola & 100,00 & 100,00 & 100,00 & 100,00 & 0,00 & ÖD \\
\hline Gübre Ort. & 96,54 & 96,88 & 95,50 & & & \\
\hline $\mathrm{OSH}$ & 2,41 & 2,22 & 2,51 & & & \\
\hline $\mathrm{P}$ & ÖD & ÖD & ÖD & Gübre x Çeşit & & ÖD \\
\hline
\end{tabular}

$* \mathrm{P}<0,05 ; * * \mathrm{P}<0,01 ;$ ÖD, $\mathrm{P}>0,05$, Farklı harflerle verilen satır ve sütunlardaki ortalamalar birbirinden istatistiki olarak farklıdır, ÖD=Önemli Değil, OSH=Ortalama Standart Hata

Tablo 5 Uygulamalardan üretilen bitkilerin boyu $(\mathrm{cm})$

\begin{tabular}{|c|c|c|c|c|c|c|}
\hline \multirow{2}{*}{ Çeşitler } & \multicolumn{3}{|c|}{ Gübre uygulamaları } & \multirow{2}{*}{ Çeşit Ort. } & \multirow{2}{*}{ OSH } & \multirow[t]{2}{*}{$\mathrm{P}$} \\
\hline & Organomineral & Kompost & Fermente & & & \\
\hline Madaline & 44,67 & 46,00 & 48,00 & 46,22 & 1,06 & ÖD \\
\hline Provento & 54,00 & 47,33 & 50,67 & 50,67 & 2,17 & ÖD \\
\hline Marfona & 50,67 & 50,33 & 43,67 & 48,22 & 1,66 & ÖD \\
\hline Agata & 48,00 & 40,33 & 39,67 & 42,67 & 2,76 & ÖD \\
\hline Arizona & 51,67 & 46,33 & 43,33 & 47,11 & 1,49 & ÖD \\
\hline Mustang & 49,67 & 51,00 & 45,33 & 48,67 & 2,19 & ÖD \\
\hline Rumba & 44,00 & 45,00 & 44,33 & 44,44 & 2,59 & ÖD \\
\hline Saviola & 48,33 & 52,00 & 50,33 & 50,22 & 0,88 & ÖD \\
\hline Gübre Ort. & 48,88 & 47,29 & 45,67 & & & \\
\hline $\mathrm{OSH}$ & 1,33 & 1,19 & 1,21 & & & \\
\hline $\mathrm{P}$ & ÖD & ÖD & ÖD & Gübre x Çeşit & & ÖD \\
\hline
\end{tabular}

$* \mathrm{P}<0,05 ; * * \mathrm{P}<0,01 ;$ ÖD, $\mathrm{P}>0,05$, Farklı harflerle verilen satır ve sütunlardaki ortalamalar birbirinden istatistiki olarak farklıdır, ÖD=Önemli Değil, OSH=Ortalama Standart Hata

Tablo 6 Uygulamalardan üretilen bitkilerin ana sap sayısı (adet)

\begin{tabular}{|c|c|c|c|c|c|c|}
\hline \multirow{2}{*}{ Çeşitler } & \multicolumn{3}{|c|}{ Gübre uygulamaları } & \multirow{2}{*}{ Çeşit Ort. } & \multirow{2}{*}{ OSH } & \multirow{2}{*}{$\mathrm{P}$} \\
\hline & Organomineral & Kompost & Fermente & & & \\
\hline Madaline & 8,00 & 8,00 & 8,00 & 8,00 & 0,00 & ÖD \\
\hline Provento & 7,67 & 8,00 & 7,67 & 7,78 & 0,15 & ÖD \\
\hline Marfona & 8,00 & 7,33 & 8,00 & 7,78 & 0,15 & ÖD \\
\hline Agata & 7,67 & 7,67 & 7,67 & 7,67 & 0,17 & ÖD \\
\hline Arizona & 7,33 & 8,33 & 8,00 & 7,89 & 0,20 & ÖD \\
\hline Mustang & 8,00 & 7,33 & 8,00 & 7,78 & 0,15 & ÖD \\
\hline Rumba & 8,00 & 8,00 & 8,00 & 8,00 & 0,00 & ÖD \\
\hline Saviola & 8,00 & 8,00 & 8,00 & 8,00 & 0,00 & ÖD \\
\hline Gübre Ort. & 7,83 & 7,83 & 7,92 & & & \\
\hline $\mathrm{OSH}$ & 0,08 & 0,10 & 0,06 & & & \\
\hline $\mathrm{P}$ & ÖD & ÖD & ÖD & Gübre x Çeşit & & ÖD \\
\hline
\end{tabular}

$* \mathrm{P}<0,05 ; * * \mathrm{P}<0,01 ;$ ÖD, $\mathrm{P}>0,05$, Farklı harflerle verilen satır ve sütunlardaki ortalamalar birbirinden istatistiki olarak farklıdır, ÖD=Önemli Değil, OSH=Ortalama Standart Hata

Bitki boyu: Araştırmada kullanılan çeşitlerin bitki boyları ve kullanılan taban gübresinin etkilerini içeren varyans analizi değerleri Tablo 5'de verilmiștir.

Kullanılan çeşitlerin ortalama bitki boyları arasında önemli bir farklılık bulunmamış $(\mathrm{P}>0,05)$, benzer şekilde taban gübresi formlarının ortalama bitki boyları üzerine önemli bir etkisi gözlenmemiştir $(\mathrm{P}>0,05)$. Önemli Gübre $\mathrm{x}$ Çeşit interaksiyonu hesaplanmamıştır $(\mathrm{P}>0,05)$.

Çeşitlerin bitki boyu değerleri 42,67 - 50,67 cm arasında değişmekle birlikte ortalama değerler arasında istatistiksel bakımdan önemli bir farklılık bulunmadığından genel ortalama $47,27 \mathrm{~cm}$ olarak hesaplanmıştır. Gübre formlarından elde edilen bitki boyu değerleri 45,67 - 48,88 cm arasında değişmektedir. Çeşit ortalama değerlerine benzer şekilde gübre ortalamaları arasında önemli bir farklılık bulunmadığından bitki boyu bakımından gübre faktörünün ortalama etkisi $47,28 \mathrm{~cm}$ olarak hesaplanmıştır. Gübre $\mathrm{x}$ Çeşit interaksiyonu önemsiz $(\mathrm{P}>0,05)$ olarak hesaplanmıştır.

Bitkilerin ana sap sayısı: Taban gübresi formalarından Organomineral, kompost ve fermente tavuk gübresi uygulamalarının araştırmada kullanılan çeşitlerin ana sap sayısı üzerine etkilerine ilişkin veriler Tablo 6'da verilmiştir. 
Çeşitlerin ana sap sayıları arasında gözlenen farklılık önemsiz $(\mathrm{P}>0,05)$ olarak gerçekleşmiş, gübre uygulamasının çeşit ana sap sayıları üzerine önemli bir etkisi olmamıştır $(\mathrm{P}>0,05)$. Benzer şekilde Gübre x Çeşit interaksiyonu önemsiz olarak hesaplanmıştır $(\mathrm{P}>0,05)$.

Çeşitlerden elde edilen ortalama ana sap sayıları $7,67-8,00$ adet arasında değişmekte, ortalamalar arasında önemli bir farklılık bulunmadığından çeşitlerin genel ortalama ana sap sayis1 7,86 adet olarak hesaplanmış, benzer şekilde gübre uygulamalarının ortalama ana sap sayısı da 7,76 adet olarak belirlenmiștir.

Gübre x Çeşit interaksiyonu önemsiz $(\mathrm{P}>0,05)$ olarak hesaplanmıştır.

Ocak başına yumru verimi: Taban gübresi formalarından Organomineral, kompost ve fermente tavuk gübresi uygulamalarının araştırmada kullanılan çeşitlerin ocak başına yumru verimi üzerine etkilerine ilişkin veriler Tablo 7'de verilmiştir.

Çeşitlerin ocak başına yumru verimleri arasındaki fark önemlidir $(\mathrm{P}<0,01)$. Benzer şekilde, taban gübresi uygulamalarının çeşitlerin ocak başına verimleri üzerine etkileri de önemli bulunmuştur $(\mathrm{P}<0,01)$. Gübre x Çeşit interaksiyonu önemli olarak hesaplanmıştır $(\mathrm{P}<0,05)$.

Çeşitler arasında ocak başına yumru verimi bakımından en yüksek değer Arizona çeşidinde elde edilmiş $(1258,56 \mathrm{~g})$, en düşük verim ise Marfona (836,44 g), Agata $(757,22 \mathrm{~g})$ ve Rumba $(858,89 \mathrm{~g})$ çeşitlerinde gerçekleşmiştir.

Taban gübresi olarak kullanılan Organomineral gübre uygulamasından ocak başına en yüksek verim elde edilmiş $(1028,08 \mathrm{~g})$, kompost $(915,13 \mathrm{~g})$ ve fermente $(890,96 \mathrm{~g})$ tavuk gübrelerinin ocak başına verimleri benzer olarak gerçekleşmiştir.

Toplam yumru verimi: Taban gübresi formalarından Organomineral, kompost ve fermente tavuk gübresi uygulamalarının araştırmada kullanılan çeşitlerin toplam yumru verimi üzerine etkilerine ilişkin veriler Tablo 8'de verilmiştir.

Çeşitlerden elde edilen toplam yumru verimi ortalamaları arasındaki fark önemlidir $(\mathrm{P}<0,01)$. Kullanılan gübre ortalamaları arasındaki fark önemsiz bulunmuştur $(\mathrm{P}>0,05)$.

Toplam yumru verimi en yüksek olan çeşit Arizona (8055 kg/dekar), en düşük çeşit ise Agata (4277 kg/dekar) olarak gerçekleşmiştir. Gübre uygulamaları arasında fark önemsiz olup Organomineral, kompost ve fermente tavuk gübrelerinden elde edilen ortalama toplam yumru verimi sirasiyla 6410, 5742 ve $5532 \mathrm{~kg} /$ dekar olarak hesaplanmıştır.

Gübre $\mathrm{x}$ Çeşit interaksiyonu önemsiz $(\mathrm{P}>0,05)$ olarak hesaplanmıştır.

Çatlak yumru oranı: Taban gübresi formalarından Organomineral, kompost ve fermente tavuk gübresi uygulamalarının araştırmada kullanılan çeşitlerden elde edilen çatlak yumru oranı üzerine etkilerine ilişkin veriler Tablo 9'da verilmiştir.

Taban gübresi formlarının çeşitlerden elde edilen çatlak yumru verimi üzerine etkileri arasında önemli bir farklı1ığa rastlanmamıştır $(\mathrm{P}>0,05)$. Organomineral, kompost ve fermente tavuk gübrelerinden elde edilen çatlak yumru oranları sırasıyla $\% 28,50 ; \% 31,08$ ve \%36,42 olarak hesaplanmıştır.

Çeşitlerden elde edilen \% çatlak yumru verimi ortalamaları arasındaki fark önemlidir $(\mathrm{P}<0,05)$. En yüksek çatlak yumru verimi \%48,67 ile Mustang'da, en düşük çatlak yumru verimi Prevento $(\% 27,22)$, Marfona $(29,56)$ ve Arizona $(25,11)$ çeşitlerinde gerçekleşmiştir.

Gübre $\mathrm{x}$ Çeşit interaksiyonu önemsiz $(\mathrm{P}>0,05)$ olarak hesaplanmıştır.

Kuru madde içeriği: Taban gübresi formalarından Organomineral, kompost ve fermente tavuk gübresi uygulamalarının araştırmada kullanılan çeşitlerden elde edilen kuru madde içeriği üzerine etkilerine ilişkin veriler Tablo 10'da verilmiştir.

Taban gübresi formlarının çeşitlerden elde edilen kuru madde içeriği üzerine etkileri arasında önemli bir farklılığa rastlanmamıştır $(\mathrm{P}>0,05)$. Organomineral, kompost ve fermente tavuk gübrelerinden elde edilen kuru madde içeriği sırasıyla $\% 17,81 ; \% 18,05$ ve $\% 18,22$ olarak hesaplanmıştır.

Çeşitlerden elde edilen kuru madde içeriğ $i$ ortalamalar1 arasındaki fark önemlidir $(\mathrm{P}<0,01)$. En yüksek kuru madde oranı \%21,56 ile Rumba'da, en düşük kuru madde oranı Mustang $(\% 17,73)$ çeşitlerinde gerçekleşmiştir.

Gübre $\mathrm{x}$ Çeşit interaksiyonu önemsiz $(\mathrm{P}>0,05)$ olarak hesaplanmıştır.

Tablo 7 Uygulamalardan üretilen bitkilerin ocak başına yumru verimi (gr)

\begin{tabular}{|c|c|c|c|c|c|c|}
\hline \multirow{2}{*}{ Çeşitler } & \multicolumn{3}{|c|}{ Gübre uygulamaları } & \multirow{2}{*}{ Çeşit Ort. } & \multirow{2}{*}{$\mathrm{OSH}$} & \multirow{2}{*}{$\mathrm{P}$} \\
\hline & Organomineral & Kompost & Fermente & & & \\
\hline Madaline & 904,33 & 1009,00 & 873,00 & $928,78^{b c}$ & 41,35 & $* *$ \\
\hline Provento & 1242,33 & 775,67 & 1101,00 & $1039,67^{b}$ & 73,74 & $* *$ \\
\hline Marfona & 857,33 & 855,67 & 796,33 & $836,44^{\mathrm{c}}$ & 19,68 & $* *$ \\
\hline Agata & 907,33 & 720,33 & 644,00 & $757,22^{c}$ & 56,14 & $* *$ \\
\hline Arizona & 1552,33 & 1168,67 & 1054,67 & $1258,56^{\mathrm{a}}$ & 84,39 & $* *$ \\
\hline Mustang & 898,00 & 716,33 & 827,00 & $813,78^{\mathrm{c}}$ & 43,50 & $* *$ \\
\hline Rumba & 739,33 & 946,33 & 891,00 & $858,89^{\mathrm{c}}$ & 98,11 & $* *$ \\
\hline Saviola & 1123,67 & 1129,00 & 940,67 & $1064,44^{\mathrm{b}}$ & 69,42 & $* *$ \\
\hline Gübre Ort. & $1028,08^{\mathrm{a}}$ & $915,13^{b}$ & $890,96^{b}$ & & & \\
\hline $\mathrm{OSH}$ & 55,11 & 47,07 & 43,47 & & & \\
\hline $\mathrm{P}$ & $*$ & $*$ & $*$ & Gübre x Çeşit & & $*$ \\
\hline
\end{tabular}

${ }^{*} \mathrm{P}<0,05 ; * * \mathrm{P}<0,01 ;$ ÖD, $\mathrm{P}>0,05$, Farklı harflerle verilen satır ve sütunlardaki ortalamalar birbirinden istatistiki olarak farklıdır, ÖD=Önemli Değil, OSH=Ortalama Standart Hata 
Tablo 8 Uygulamalardan üretilen bitkilerin toplam yumru verimi (kg/dekar)

\begin{tabular}{|c|c|c|c|c|c|c|}
\hline \multirow{2}{*}{ Çeşitler } & \multicolumn{3}{|c|}{ Gübre uygulamaları } & \multirow{2}{*}{ Çeşit Ort. } & \multirow{2}{*}{$\mathrm{OSH}$} & \multirow{2}{*}{$\mathrm{P}$} \\
\hline & Organomineral & Kompost & Fermente & & & \\
\hline Madaline & 5788 & 6459 & 5588 & $5945^{\text {bcd }}$ & 265 & $* *$ \\
\hline Provento & 7949 & 4540 & 7046 & $6512^{\mathrm{bc}}$ & 569 & $* *$ \\
\hline Marfona & 5488 & 5476 & 5097 & $5354^{\mathrm{cd}}$ & 126 & $* *$ \\
\hline Agata & 5022 & 4608 & 3200 & $4277^{\mathrm{d}}$ & 479 & $* *$ \\
\hline Arizona & 9936 & 7481 & 6749 & $8055^{\mathrm{a}}$ & 540 & $* *$ \\
\hline Mustang & 5747 & 4585 & 4858 & $5063^{\mathrm{cd}}$ & 353 & $* *$ \\
\hline Rumba & 4160 & 5562 & 5703 & $5142^{\mathrm{cd}}$ & 791 & $* *$ \\
\hline Saviola & 7191 & 7224 & 6018 & $6811^{\mathrm{ab}}$ & 444 & $* *$ \\
\hline Gübre Ort. & 6410 & 5742 & 5532 & & & \\
\hline $\mathrm{OSH}$ & 398 & 344 & 338 & & & \\
\hline $\mathrm{P}$ & ÖD & ÖD & ÖD & Gübre x Çeşit & & ÖD \\
\hline
\end{tabular}

$* \mathrm{P}<0,05 ; * * \mathrm{P}<0,01 ;$ ÖD, $\mathrm{P}>0,05$, Farklı harflerle verilen satır ve sütunlardaki ortalamalar birbirinden istatistiki olarak farklıdır, ÖD=Önemli Değil, OSH=Ortalama Standart Hata

Tablo 9 Uygulamalardan üretilen çatlak yumru oranı (\%)

\begin{tabular}{|c|c|c|c|c|c|c|}
\hline \multirow{2}{*}{ Çeşitler } & \multicolumn{3}{|c|}{ Gübre uygulamaları } & \multirow{2}{*}{ Çeşit Ort. } & \multirow{2}{*}{$\mathrm{OSH}$} & \multirow{2}{*}{$\mathrm{P}$} \\
\hline & Organomineral & Kompost & Fermente & & & \\
\hline Madaline & 29,33 & 28,00 & 50,33 & $35,89^{\mathrm{ab}}$ & 5,47 & $*$ \\
\hline Provento & 28,67 & 31,00 & 22,00 & $27,22^{\mathrm{c}}$ & 4,36 & $*$ \\
\hline Marfona & 21,33 & 36,00 & 31,33 & $29,56^{\mathrm{c}}$ & 3,70 & $*$ \\
\hline Agata & 25,67 & 29,00 & 50,33 & $35,00^{\mathrm{ab}}$ & 5,45 & $*$ \\
\hline Arizona & 25,67 & 25,33 & 24,33 & $25,11^{\mathrm{c}}$ & 2,76 & * \\
\hline Mustang & 41,00 & 49,00 & 56,00 & $48,67^{\mathrm{a}}$ & 6,09 & $*$ \\
\hline Rumba & 41,33 & 32,33 & 32,33 & $35,33^{\mathrm{ab}}$ & 7,51 & $*$ \\
\hline Saviola & 15,00 & 18,00 & 24,67 & $19,22^{\mathrm{c}}$ & 3,42 & $*$ \\
\hline Gübre Ort. & 28,50 & 31,08 & 36,42 & & & \\
\hline $\mathrm{OSH}$ & 3,24 & 3,07 & 3,80 & & & \\
\hline $\mathrm{P}$ & ÖD & ÖD & ÖD & Gübre x Çeşit & & ÖD \\
\hline
\end{tabular}

$* \mathrm{P}<0,05 ; * * \mathrm{P}<0,01 ;$ ÖD, $\mathrm{P}>0,05$, Farklı harflerle verilen satır ve sütunlardaki ortalamalar birbirinden istatistiki olarak farklıdır, ÖD=Önemli Değil, OSH=Ortalama Standart Hata

Tablo 10 Uygulamalardan üretilen yumruların kuru madde içeriği (\%)

\begin{tabular}{|c|c|c|c|c|c|c|}
\hline \multirow{2}{*}{ Çeşitler } & \multicolumn{3}{|c|}{ Gübre uygulamaları } & \multirow{2}{*}{ Çeşit Ort. } & \multirow{2}{*}{$\mathrm{OSH}$} & \multirow{2}{*}{$\mathrm{P}$} \\
\hline & Organomineral & Kompost & Fermente & & & \\
\hline Madaline & 19,82 & 19,72 & 20,50 & $20,02^{b}$ & 0,68 & $* *$ \\
\hline Provento & 18,37 & 19,33 & 18,94 & $18,88^{\mathrm{c}}$ & 0,22 & $* *$ \\
\hline Marfona & 15,74 & 15,39 & 16,01 & $15,71^{\mathrm{g}}$ & 0,14 & $* *$ \\
\hline Agata & 15,80 & 16,46 & 16,26 & $16,17^{\mathrm{fg}}$ & 0,14 & $* *$ \\
\hline Arizona & 17,04 & 16,96 & 18,05 & $17,35^{\mathrm{de}}$ & 0,25 & $* *$ \\
\hline Mustang & 17,85 & 17,94 & 17,38 & $17,73^{\mathrm{d}}$ & 0,17 & $* *$ \\
\hline Rumba & 20,92 & 21,82 & 21,95 & $21,56^{\mathrm{a}}$ & 0,24 & $* *$ \\
\hline Saviola & 16,90 & 16,81 & 16,65 & $16,79^{\mathrm{ef}}$ & 0,06 & $* *$ \\
\hline Gübre Ort. & 17,81 & 18,05 & 18,22 & & & \\
\hline $\mathrm{OSH}$ & 0,40 & 0,45 & 0,42 & & & \\
\hline $\mathrm{P}$ & ÖD & ÖD & ÖD & Gübre x Çeşit & & ÖD \\
\hline
\end{tabular}

$* \mathrm{P}<0,05 ; * * \mathrm{P}<0,01 ;$ ÖD, $\mathrm{P}>0,05$, Farklı harflerle verilen satır ve sütunlardaki ortalamalar birbirinden istatistiki olarak farklıdır, ÖD=Önemli Değil, OSH=Ortalama Standart Hata

Nişasta içeriği: Taban gübresi formalarından Organomineral, kompost ve fermente tavuk gübresi uygulamalarının araştırmada kullanılan çeşitlerin nişasta içeriği üzerine etkilerine ilişkin veriler Tablo 11 'de verilmiştir.

Taban gübresi formlarının çeşitlerden elde edilen nişasta içeriği üzerine etkileri arasında önemli bir farklılığa rastlanmamıştır $(\mathrm{P}>0,05)$. Organomineral, kompost ve fermente tavuk gübrelerinden elde edilen nişasta içeriği sırasıyla \%12,04; \%11,92 ve \%12,23 olarak hesaplanmıştır.
Çeşitlerden elde edilen nişasta içeriği ortalamaları arasındaki fark önemlidir $(\mathrm{P}<0,01)$. En yüksek kuru madde oran $1 \% 15,50$ ile Rumba ve $\% 15,13$ ile Madaline'da, en düşük kuru madde oranı Marfona $(\% 9,39)$ çeşitlerinde gerçekleşmiştir.

Gübre $x$ Çeşit interaksiyonu önemsiz $(\mathrm{P}>0,05)$ olarak hesaplanmıştır.

Özgül ă̌lrlı̆̆g: Taban gübresi formalarından Organomineral, kompost ve fermente tavuk gübresi uygulamalarının araştırmada kullanılan çeşitlerin özgül ağırlığı üzerine etkilerine ilişkin veriler Tablo 12 'de verilmiştir. 
Taban gübresi formlarının çeşitlerden elde edilen özgül ağırlığı üzerine etkileri arasında önemli bir farklılığa rastlanmamıştır $(\mathrm{P}>0,05)$. Organomineral, kompost ve fermente tavuk gübrelerinden elde edilen özgül ağırlık değerleri sırasıyla 1,068, 1.070 ve 1,071 olarak hesaplanmıştır.

Çeşitlerden elde edilen özgül ağırlık ortalamaları arasındaki fark önemlidir $(\mathrm{P}<0,01)$. En yüksek özgül ağırlık 1,087 ile Madaline'da, en düşük özgül ağırlık Marfona $(1,059)$ çeşitlerinde gerçekleşmiştir.

Gübre x Çeşit interaksiyonu önemli $(\mathrm{P}<0,01)$ olarak hesaplanmıştır.

\section{Tartışma}

Yumruların çıkış süreleri ve oranları: Taban gübresi olarak Organomineral, kompost ve fermente tavuk gübresi kullanımının denemede kullanılan çeşitlerin çıkış süreleri üzerine farklı bir etkisi bulunmamıştır. Sivas koşullarında çıkış sürelerinin ortalaması 26,70 gün olarak belirlenebilir. Ortalama çıkış oranları dikkate alındığında, kullanılan gübre formlarının çeşitlerin çıkış oranı üzerine olumsuz bir etkisinin bulunmadığı, benzer şekilde Organomineral, kompost ve fermente tavuk gübrelerinin çeşitlerin çıkış oranlarında farklılığa neden olmadığı görülmekte, genel çıkış oranı \%96,30 olarak hesaplanmaktadır. Gerek kimyasal ve gerekse tavuk dışkısının farklı yöntemle işlenmesinden elde edilen gübrelerin tohumluk patates üretiminde kullanılmasıyla elde edilen çıkış süresi değerlerinin literatür bildirimleri ile uyum içinde olduğu gözlenmektedir (Tunçtürk ve ark., 2004; Kara, 2002; Karacapınar, 2007; Okur, 2008).

Çeşitlerin çıkış oranları ortalamaları \%86,78-\%100,00 arasında değişmekte, ortalamalar arasında önemli bir farklılık bulunmadığından genel olarak çıkış oranı \%96,30 olarak hesaplanmaktadır. Ortalama çıkış oranları dikkate alındığında, kullanılan gübre formlarının çeşitlerin çıkış oranı üzerine olumsuz bir etkisinin bulunmadığı, benzer şekilde kimyasal, kompost ve fermente tavuk gübrelerinin çeşitlerin çıkış oranlarında farklılığa neden olmadığı görülmektedir. Elde edilen ortalama değerler literatür bildirimleri ile uyum içindedir (Okur, 2008; Zamudio ve ark., 1986; Ülger, 1971; Kara, 2002).
Yurt dışından ithal edilen çeşitlere ait yumruların aynı firmada eş zamanlı olarak üretiliyor olması, yumruların fizyolojik yaşlarının aynı olmasına neden olmakta, bu durum çeşitlerin çıkış süreleri arasında önemli bir farklılığının bulunmamasının nedenleri arasında gösterilebilmektedir.

Bitki boyu: Kara (2002), aynı ekolojik şartlarda 20 patates çeşidinden en fazla bitki boyunu Agria (60,15 cm) çeşidinden elde etmiştir. Güler ve Kolsarıcı (1995), Çorum ilinde iki farklı lokasyonda 7 patates çeşidini kullanarak yürüttükleri çalışmada, çeşitlerin bitki boyunu 31.4-91.2 cm olarak tespit etmişlerdir.

Tunçtürk ve ark. (2004), iki yıllık ortalama değerlere göre farklı sıra üzeri mesafelerde oluşan bitki boyları $53,1-55,1 \mathrm{~cm}$ arasında oluştuğunu, iki yıllık ortalama değerlere göre farklı azot dozlarında bitki boylarının ise 49.00 - 58,6 cm değerleri arasında değişiklik gösterdiğini bildirmişlerdir.

Bitki boyu bir çeşit özelliği ve genetik yapıya bağlı olmakla beraber (Günel ve ark., 1991; Öztürk ve ark., 2008) bitki sıklığı, güneşlenme, sıcaklık, hava ve toprak nemi ile toprak verimliliği gibi ekolojik şartlar da bitki boyunu etkilemektedir. Araştırma sonucunda çeşitlerden elde edilen bitki boyu değerleri, bu konu ile ilgili olarak çalışan diğer araştırıcıların (Kara ve ark., 1986; Kara 2002; Güler ve Kolsarıcı, 1995: İncekara ve Çalışkan, 1980; Çalışkan ve ark., 1997; Öztürk ve ark., 2008) buldukları sonuçlarla benzerlik göstermektedir.

Karacapınar (2007), yaptıkları araştırmada uygulamalar arasındaki rakamsal değerlerin oldukça birbirine yakın çıktığını, uygulamalara göre bitki boyu değerlerinin 28,47-33,59 cm arasında değişim gösterdiğini bildirmiştir.

Bitkilerin ana sap sayısı: Taban gübresi formalarından Organomineral, kompost ve fermente tavuk gübresi uygulamalarının araştırmada kullanılan çeşitlerin ana sap sayıları arasında gözlenen farklılık önemsiz olarak gerçekleşmiş, gübre uygulamasının çeşit ana sap sayıları üzerine önemli bir etkisi olmamıştır. Çeşitlerden elde edilen ortalama ana sap sayıları 7,67-8,00 adet arasında değişmekte, ortalamalar arasında önemli bir farklılık bulunmadığından çeşitlerin genel ortalama ana sap sayısı 7,86 adet olarak hesaplanmış, benzer şekilde gübre uygulamalarının ortalama ana sap sayısı da 7,76 adet olarak belirlenmiştir.

Tablo 11 Uygulamalardan üretilen yumruların nişasta içeriği (\%)

\begin{tabular}{|c|c|c|c|c|c|c|}
\hline \multirow{2}{*}{ Çeşitler } & \multicolumn{3}{|c|}{ Gübre uygulamaları } & \multirow{2}{*}{ Çeşit Ort. } & \multirow{2}{*}{$\mathrm{OSH}$} & \multirow{2}{*}{$\mathrm{P}$} \\
\hline & Organomineral & Kompost & Fermente & & & \\
\hline Madaline & 15,44 & 14,45 & 15,49 & $15,13^{\mathrm{a}}$ & 0,67 & $* *$ \\
\hline Provento & 12,01 & 12,97 & 12,69 & $12,56^{\mathrm{b}}$ & 0,23 & $* *$ \\
\hline Marfona & 9,66 & 8,97 & 9,54 & $9,39^{\mathrm{e}}$ & 0,15 & $* *$ \\
\hline Agata & 10,39 & 10,51 & 10,49 & $10,46^{\mathrm{d}}$ & 0,11 & $* *$ \\
\hline Arizona & 11,63 & 11,38 & 12,08 & $11,69^{\mathrm{bc}}$ & 0,18 & $* *$ \\
\hline Mustang & 11,01 & 11,67 & 11,02 & $11,24^{\mathrm{cd}}$ & 0,18 & $* *$ \\
\hline Rumba & 15,28 & 15,01 & 16,21 & $15,50^{\mathrm{a}}$ & 0,24 & $* *$ \\
\hline Saviola & 10,89 & 10,44 & 10,35 & $10,56^{\mathrm{d}}$ & 0,15 & $* *$ \\
\hline Gübre Ort. & 12,04 & 11,92 & 12,23 & & & \\
\hline OSH & 0,44 & 0,46 & 0,49 & & & \\
\hline $\mathrm{P}$ & ÖD & ÖD & ÖD & Gübre x Çeşit & & ÖD \\
\hline
\end{tabular}


Tablo 12 Uygulamalardan üretilen yumruların özgül ağırlığg

\begin{tabular}{|c|c|c|c|c|c|c|}
\hline \multirow{2}{*}{ Çeşitler } & \multicolumn{3}{|c|}{ Gübre uygulamaları } & \multirow{2}{*}{ Çeşit Ort. } & \multirow{2}{*}{$\mathrm{OSH}$} & \multirow{2}{*}{$\mathrm{P}$} \\
\hline & Organomineral & Kompost & Fermente & & & \\
\hline Madaline & 1,091 & 1,082 & 1,087 & $1,087^{\mathrm{a}}$ & 0,0032 & $* *$ \\
\hline Provento & 1,071 & 1,073 & 1,074 & $1,073^{\mathrm{c}}$ & 0,0011 & $* *$ \\
\hline Marfona & 1,059 & 1,057 & 1,060 & $1,059^{\mathrm{e}}$ & 0,0007 & $* *$ \\
\hline Agata & 1,063 & 1,063 & 1,062 & $1,063^{\mathrm{de}}$ & 0,0004 & $* *$ \\
\hline Arizona & 1,070 & 1,066 & 1,069 & $1,068^{\mathrm{c}}$ & 0,0009 & $* *$ \\
\hline Mustang & 1,069 & 1,071 & 1,067 & $1,069^{\mathrm{c}}$ & 0,0007 & $* *$ \\
\hline Rumba & 1,061 & 1,086 & 1,087 & $1,078^{\mathrm{b}}$ & 0,0048 & $* *$ \\
\hline Saviola & 1,064 & 1,064 & 1,063 & $1,063^{\mathrm{d}}$ & 0,0004 & $* *$ \\
\hline Gübre Ort. & 1,068 & 1,070 & 1,071 & & & \\
\hline $\mathrm{OSH}$ & 0,0021 & 0,0022 & 0,0022 & & & \\
\hline $\mathrm{P}$ & ÖD & ÖD & ÖD & Gübre x Çeşit & & $* *$ \\
\hline
\end{tabular}

OSH=Ortalama Standart Hata

Öztürk ve ark (2008)'ın çalışmasında, Çeşitlerin sap sayısı 4,2 ile 5,7 adet arasında değişmiştir. Horizon $(5,7$ adet) ilk sırayı almış, bu çeşidi Granola (5,1 adet) ve Marfona (5,2 adet), takip etmiştir. Desire (4,3 adet) ve Hermes'de (4,2 adet) ise en az sap sayısı tespit edilmiştir.

Samul (1982), Değişik dozlardaki azot uygulamasının 3 patates çeşidinin verim ve bazı özelliklerine etkisini incelemiş çeşitlere göre değişmek üzere, ocak başına ortalama sap sayısının 14,3-15,4 adet arasında olduğunu ve gübre miktarıyla ilişkisinin olmadığını ifade etmiştir.

Tunçtürk ve ark. (2004), iki yıllık ortalama değerlere göre farklı sıra üzeri mesafelerde oluşan ocak başına sap sayısını 3,5-3,8 adet/ocak değerleri arasında tespit etmiştir.

Sivas yöresinde yürütülen bu çalışmadan elde edilen ana sap sayıları uygulamaları arasında fark olmayan çalışmalar ile karşılaştırıldığında Öztürk ve ark. (2008) ve Tunçtürk ve ark. (2004) araştırmalarından elde edilen değerlerden yüksek, Samul (1982) çalışmasından düşük olarak gerçekleşmiştir. Bitkilerin ana sap sayısı üzerine sıcaklığın (Çalışkan, 1989; Haverkort ve ark., 1990), 1şık kullanımının (Fahem ve Haverkort, 1988) ile birlikte çeşit faktörünün de etkili olduğu bilinmektedir. Araştırmadan elde edilen ortalama 7,76 ana sap sayıs1 kabul edilebilir değerler arasında yer almaktadır.

Ocak başına ve toplam yumru verimi: Çeşitler arasında ocak başına yumru verimi bakımından en yüksek değer Arizona çeşidinde elde edilmiş (1258,56 g), en düşük verim ise Marfona (836,44 g), Agata (757,22 g) ve Rumba $(858,89 \mathrm{~g})$ çeşitlerinde gerçekleşmiştir. Taban gübresi olarak kullanılan kimyasal gübre uygulamasından ocak başına en yüksek verim elde edilmiş (1028,08 g), kompost $(915,13 \mathrm{~g})$ ve fermente $(890,96 \mathrm{~g})$ tavuk gübrelerinin ocak başına verimleri benzer olarak gerçekleşmiştir.

Kara ve ark. (1986), Erzurum'da dış kaynaklı 14 patates çeşidini kullanarak yaptıkları çalışmada ocak başına yumru veriminin 367,9-53,2 g arasında değiştiğini, en iyi sonuçların Cosima, B-5361-1 ve Isola patates çeşitlerinden aldıklarını bildirmişlerdir. Tunçtürk ve ark. (2004), yapmış oldukları bir çalışmada ocak başına en yüksek yumru verimini 453,2 g/ocak yılların ortalaması olarak belirlemişlerdir.

Arslan ve Kevseroğlu (1991), Bafra ovasında çiftçi koşullarında Resy, Aula, Cherista çeşitlerini kullanarak yaptıkları bir araştırmada, ocak başına yumru veriminin 320-660 g, arasında değiştiğini tespit etmişlerdir. Kara (2002), aynı ekolojik şartlarda 20 patates çeşidinden ocak başına yumru verimini Agria (484.1 g/ocak) çeşidinden elde etmiştir. Güler ve Kolsarıcı (1995), Çorum ilinde iki farklı lokasyonda 7 patates çeşidini kullanarak yürüttükleri çalışmada, çeşitlerin ocak başına yumru verimini 773,7-1711,2 g olarak tespit etmişlerdir. Öztürk ve ark (2008), patates çeşitlerinin ortalama ocak başına yumru verimini $316,8 \mathrm{~g}-556,4 \mathrm{~g}$ arasında değiştiğini belirlemişlerdir. Bu konu ile ilgili yapılan çalışmalarla (Kara ve ark., 1986; Kara ,2002; Şenol, 1970; İncekara ve Çalışkan, 1980; Çalışkan ve ark., 1997; Günel, 1976; Christ, 1986) elde ettiğimiz sonuçların değerleri farklı olup, ocak başına elde edilen yumru verimi yüksek olarak gerçekleşmiştir.

Ocak başına yumru verimi bakımından gübre uygulamaları arasındaki farklılıkta çeşit faktörünün de etkisi bulunmaktadır. Ocak başına elde edilecek yumru veriminin ocak başına yumru sayısı ve ortalama tek yumru ağırlığın ortaklaşa bir fonksiyonu olduğu düşünülürse (Öztürk ve ark., 2008), bu gibi özellikler üzerine etkili olan faktörlerin ocak başına yumru verimi üzerinde de etkili olacağı yargısına varılabilir.

Patates tarımında ticari gübrelerden azotlu, fosforlu, potasyumlu gübreler verim ve kaliteye etkileri bakımından büyük önem taşır. Özellikle azotlu gübreler, bitkinin hızlı ve güçlü gelişmesi ile yumru verimine son derece olumlu etki yaparlar (Tunçtürk ve ark., 2004). Kontrol grubu olarak Organomineral gübre ile fermente ve kompost yöntemleriyle elde edilmiş olan tavuk gübrelerinin $\%$ Azot içerikleri sırasıyla $\% 8, \% 3,5$ ve $\% 2$ olup, Azot içeriği en yüksek olan Organomineral gübrede yüksek yumru verimi elde edilmiş olması bu görüşü desteklemektedir.

Toplam yumru verimi en yüksek olan çeşit Arizona (8055 kg/dekar), en düşük çeşit ise Agata (4277 kg/dekar) olarak gerçekleşmiştir. Gübre uygulamaları arasında fark önemsiz olup Organomineral, kompost ve fermente tavuk gübrelerinden elde edilen ortalama toplam yumru verimi sirasiyla 6410, 5742 ve 5532 kg/dekar olarak hesaplanmıştır.

Kara (2002), aynı ekolojik şartlarda 20 patates çeşidinden dekara yumru verimini Agria (1936,2 kg/da) çeşidinden elde etmiştir. Hatay yöresinde bazı patates 
çeşitlerinin turfanda özelliklerinin belirlenmesi amacıyla yapılan bir çalışmada 1193 ile $2203 \mathrm{~kg} /$ da arasında verim performansı gösterdikleri belirlenmiştir (Çalışkan, 2001). Niğde Patates Araştırma Enstitüsü'nde 40 ve 24 patates çeşidi ile yürütülen çalışmalarda, en yüksek verimin Cycloon çeşidinden (5206 ve $4342 \mathrm{~kg} / \mathrm{da}$ ) alındığı tespit edilmiştir (Anonim 1998, 1999). Reents ve ark. (1998) Almanyada'da 14 patates çeşidi içerisinde en yüksek yumru veriminin Agria (20,4 t/ha) çeşidinden elde edildiğini belirtmişlerdir. Tugay ve ark. (1999), Tokat koşullarında yürütülen bir çalışmada $0,10,20$ ve $30 \mathrm{~kg}$ $\mathrm{da} / \mathrm{N}$ gübre dozları değişik zamanlarda verilerek etkilerini incelemişler, ortalama yumru verimi 1483,4- 3250,9 $\mathrm{kg} / \mathrm{da}$, arasında tespit edilmiştir. Tunçtürk ve ark. (2004), araştırmalarında ortalama en yüksek yumru verimini $1449,7 \mathrm{~kg} / \mathrm{da}$ olarak belirlemişlerdir. Öztürk ve ark (2008)'na göre yapmış oldukları araştırmada, kullanılan çeşitlerin dekara yumru verimi 2271,0-1293,1 kg arasında değişmektedir. Onaran ve Arıŏlu (1999), tarafından yapılan ve ayrıca farklı yörelerdeki çalışmalarla (2 yıllık ortalama değerlere göre en yüksek yumru verimi, dikimde boyalı yumru kullanıldığında $(4944 \mathrm{~kg} / \mathrm{da})$ ve $25 \mathrm{~cm}$ sira üzeri mesafesinde $(4823 \mathrm{~kg} / \mathrm{da})$ dikim yapıldığında elde edilmiştir. En ekonomik verim ise, iri yumru kullanıldığında ve $35 \mathrm{~cm}$ mesafesinde dikim yapıldığında elde edilmiştir. Yapılan çalışmalardan elde edilen bulgular doğrultusunda dekara yumru verimi üzerine sira üzeri mesafe, çeşit özelliği, sulama ve gübre formu gibi birçok faktör etkide bulunmaktadır. Çeşitlerin yumru verimleri ile ilgili değerler daha önce Şenol (1970), Kara ve ark. (1986), Kara (2002), Çalışkan (2001), Anonim (1998,1999), Reents ve ark.(1998), tarafindan yapılan çalışmalardan elde edilen ortalama dekara yumru verimi değerlerinden yüksek olarak gerçekleşmiştir.

Çatlak yumru verimi: Yumru çatlaması, yumrunun gelişmesi sırasında yumru üzerinde çatlama gösteren fizyolojik bir anormalliktir (Hutchinson 2003). Yüzey çatlaması derinin hafif bir şekilde ayrılmasıdır. Bu çatlama şişkin yumruların ani soğuklara maruz kalması ile meydana gelmektedir (Anonim, 2008). "Sarı Cüce" veya "Patates Virüsü" ile bulaşmış yumrularda çatlak yumru gelişmesi fazla oranda görülmektedir (Anonim, 2008).

Yumrularda çatlama, yetişme şartlarında ani veya düzensiz çevresel değişmelerden kaynaklanmakta, toprak nemi ve sıcaklığı bu anormalliğin meydana gelmesine sebep olan ana faktörler arasında sayılmaktadır (Hutchinson 2003). Düşük bor düzeylerinin çatlak oluşum şiddetini arttırdığı bildirilmiştir. Aynı zamanda Pursuit gibi imidazolinonler ve Ally, Accent gibi sulfonylureas herbisitler kullanılması yumru çatlamasına sebep olabilmektedir (Anonim, 2008).

Gelişme mevsimi boyunca uygun kültürel işlemler yumru çatlamasını azaltmaktadır. Patates tarımında düzenli tesis, dengeli sulama (Günel ve Karadoğan 1993) ve gübreleme yapıldığında çatlak yumru oranında önemli seviyede azalma görülmektedir (Karadoğan ve ark., 1996). Yürütülen bu çalışmada taban gübresi formlarının çeşitlerden elde edilen çatlak yumru verimi üzerine etkileri arasında önemli bir farklılığa rastlanmamıştır. Organomineral, kompost ve fermente tavuk gübrelerinden elde edilen çatlak yumru oranları sirasıyla \%28,50; $\% 31,08$ ve \%36,42 olarak hesaplanmıştır. Uygulanmakta olan kültürel işlemlerin yerinde ve zamanında uygun olarak yapılmış olması bu sonuca etki etmiştir.

Genişleyen çatlaklara hassasiyet büyük ölçüde çeşitlere göre değişmekte olup yumru büyümesindeki ani değişmelere bağlı olarak ortaya çıkan büyüme çatlakları \% 0 ile 35,9 arasında değişmiştir (Karadoğan, 1995).

Çeşitlerden elde edilen \% çatlak yumru verimi ortalamaları arasındaki fark önemlidir. En yüksek çatlak yumru verimi \%48,67 ile Mustang'da, en düşük çatlak yumru verimi Prevento $(\% 27,22)$, Marfona $(29,56)$ ve Arizona $(25,11)$ çeşitlerinde gerçekleşmiştir. Çeşitlerin çatlak yumru verimi arasındaki farklılıkta çeşit faktörünün etkisinin olduğu söylenebilir. Elde edilen veriler Karadoğan (1995) sonuçları ile uyum içindedir.

Kuru madde içeriği, Nişasta içeriği ve Özgül ăgırlık: Patates yetiştiriciliğinde göz önüne alınması gereken önemli kriterlerden birisi de yumru kalitesidir. Üretilen ürünün kullanım gayesine göre kalitede incelenen özellikler farklı olmakla beraber, en fazla üzerinde durulan husus kuru madde ve protein miktarı ile cips rengidir (Karadoğan ve Oral, 1995). Bu kalite özellikleri çevre şartlarına, uygulanan kültürel işlemlere, çeşide ve gübre dozlarına bağlı olarak değişebilmektedir (Karadoğan ve Günel, 1992; Günel ve Karadoğan, 1992; Karadoğan, 1995; Kara, 2002).

Yürütülen bu çalışmada taban gübresi formlarının çeşitlerden elde edilen kuru madde içeriği üzerine etkileri arasında önemli bir farklılığa rastlanmamıştır. Organomineral, kompost ve fermente tavuk gübrelerinden elde edilen kuru madde içeriği sırasıyla \%17,81; \%18,05 ve $\% 18,22$ olarak hesaplanmıştır. Kuru madde oranlarının değişim sınırları Karadoğan ve Oral (1995) sonuçlarına benzerlik göstermekle birlikte azot içeriği farklı gübre formlarından beklenen farklılık bu çalışmada gerçekleşmemiştir.

Çeşitlerden elde edilen kuru madde içeriği ortalamaları arasındaki fark önemlidir. En yüksek kuru madde oranı \%21,56 ile Rumba'da, en düşük kuru madde oranı Mustang $(\% 17,73)$ çeşitlerinde gerçekleşmiştir. Kuru madde içeriği bakımından çeşitler arasındaki farkın önemli olması literatür bildirimleri ile uyum içindedir (Karadoğan ve Günel, 1992; Günel ve Karadoğan, 1992; Karadoğan, 1995; Kara, 2002).

Taban gübresi formlarının çeşitlerden elde edilen nişasta içeriği üzerine etkileri arasında önemli bir farklılığa rastlanmamıştır. Organomineral, kompost ve fermente tavuk gübrelerinden elde edilen nişasta içeriği sirasiyla $\% 12,04 ; \quad \% 11,92$ ve $\% 12,23$ olarak hesaplanmıştır.

Çeşitlerden elde edilen nişasta içeriği ortalamaları arasındaki fark önemlidir. En yüksek kuru madde oranı \%15,50 ile Rumba ve \%15,13 ile Madaline'da, en düşük kuru madde oranı Marfona $(\% 9,39)$ çeşitlerinde gerçekleşmiştir.

Nişasta değeri üzerine diğer kalite kriterlerinde olduğu gibi birçok faktör etkili olmaktadır. Bunlar arasında çeşit farklılığ1, uygulanmakta olan kültürel işlemler ile dikim zamanı üzerinde durulan etkenler arasında yer almaktadır.

Çalışkan ve İncekara (1984), verim ve kalite özellikleri bakımından en uygun dikim zamanını saptamak amacıyla beş patates çeşidinde üç yıl süreyle yaptıkları dikimlerde; en yüksek yumru verimini Şubat, Mart ve Ocak ayı dikimlerinden elde ettiklerini, Mayıs ve Haziran aylarında düşük verim elde edildiğini tespit 
etmişlerdir. Ayrıca, çeşitlerde nişasta oranını Mayıs ayındaki dikimle \%11,6, Nisan ayında \%11,7, Haziran ayında ise \%14,5 olarak tespit etmişlerdir. Karadoğan ve ark. (1997), Erzurum şartlarında 1990-91 yıllarında yaptıkları bir araştırmada, farklı azot $(0,8,16$ ve 24 $\mathrm{kg} / \mathrm{da}$ ) dozlarının patatesin bazı kalite özellikleri üzerine etkilerini incelemişler, azot dozunun artışına paralel olarak, protein oranında artma, nişasta ve kuru madde oranında ise azalma görüldüğünü bildirmişlerdir. Tunçtürk ve ark. (2004), Yılların birleştirilmiş ortalamasına göre elde edilen nişasta oranları, farklı sıra üzeri $(40,50,60 \mathrm{~cm})$ mesafelerinde $\% 13,4, \% 13,4$ ve \%12,6 değerlerinde oluşmuştur.

Araştırmada kullanılan gübre formlarının azot içeriğindeki farklılık, yumruların nişasta değerini etkilemeyecek kadar az olduğundan bu bakımdan Karadoğan ve ark. (1997) çalışmasından farklı bir sonuç elde edilmiştir. Diğer taraftan çeşitler arasında nişasta değeri bakımından gözlenen farklılık Çalışkan ve İncekara (1984) sonuçları ile uyumlu olarak bulunmuştur. Genel olarak nişasta içeriği literatür bildirimleri ile uygun sınırlar arasında kalmıştır (Çalışkan ve İncekara, 1984; Tunçtürk ve ark., 2004; Karadoğan ve ark., 1997).

Taban gübresi formlarının çeşitlerden elde edilen özgül ağırlığı üzerine etkileri arasında önemli bir farklılığa rastlanmamıştır Organomineral, kompost ve fermente tavuk gübrelerinden elde edilen özgül ağırlık değerleri sirasıyla 1,$068 ; 1.070$ ve 1,071 olarak hesaplanmıştır.

Güler ve ark. (2011), hayvan gübresinin kullanıldığ organik patates yetiştirme araştırmasında yumrunun kuru madde miktarı ve özgül ağırlık değerleri bakımından organik ve geleneksel yöntem arasında farklılığın bulunmadığını belirmişlerdir. Organomineral, kompost ve fermente tavuk gübrelerinden elde edilen özgül ağırlık değerleri arasında farklılığın bulunmaması Güler ve ark. (2011) sonuçları ile uyumludur.

Çeşitlerden elde edilen özgül ağırlık ortalamaları arasındaki fark önemlidir En yüksek özgül ağırlık 1,087 ile Madaline'da, en düşük özgül ağırlık Marfona $(1,059)$ çeşitlerinde gerçekleşmiştir. Polat ve ark. (2008), Erzurum ekolojik şartlarında adaptasyona alınan 12 patates çeşidinin bazı kalite özelliklerini tespit etmek amacıyla yaptıkları çalışmada çeşitler arasında özgül ağırlık değerleri bakımından önemli farklılıklar belirlemişler, çeşitlerin özgül ağırlık değerlerinin 1.0671.092 arasında değiştiğini bildirmişleridir. Didin ve Fenercioğlu (1999), çalışmasında bulgularımıza benzer şekilde yumru özgül ağırlığı bakımından kullandığı 12 patates çeşidi arasında önemli farklılıklar tespit ettiklerini, özgül ağırlığın 1,063-1,111 arasında değiştiğini belirlemişlerdir. Çeşitler arasında özgül ağırlık bakımından belirlenen farklılık yapılan bu çalışmalardan elde edilen sonuçlar ile uyum içindedir.

Taşkıran ve Esendal (1988), dikim zamanı geciktikçe yumru özgül ağırlığının arttığını tespit etmişlerdir. Arslan ve Kevseroğlu (1991), Resy, Aula, Semena, Planta, Cherista çeşitlerini kullanarak yaptıkları bir araştırmada; özgül ağırlığın 1,088-1,093 arasında değiştiğini belirlemişlerdir. Günel ve Karadoğan (1992)'in diş kaynaklı 30 patates çeşidi ile Erzurum ekolojik koşullarında yaptıkları bir araştırmada; üç yılın ortalamalarına göre yetişme özgül ağırlıklarının 1,064-
1,098 arasında değiştiğini tespit etmişlerdir. Yıldırım ve ark. (2005), değişik dikim zamanlarının yumru verim unsurları üzerine etkilerini belirlemek üzere yapmış oldukları çalışmada ortalama değerlere göre en yüksek yumru özgül ağırlığı 1,076 ile Arinda çeşidinden elde edilirken en düşük yumru özgül ağırlığı 1,066 ile Binella çeşidinden elde etmişlerdir. Özgür ağırlık üzerine etkili olan faktörlerin başında dikim zamanı, çeşit farklılığı ile ilgili yapılan çalışmalardan elde edilen sonuçlar ile bu çalışmadan elde edilen özgül ağırlık sınır değerleri uyum içindedir.

\section{Teşekkür}

$\mathrm{Bu}$ çalışma Cumhuriyet Üniversitesi Bilimsel Araştırma Projeleri (CUBAP) tarafindan ENF-005 nolu proje kapsamında desteklenmiştir.

\section{Sonuç}

Araştırma sonuçlarına göre farklı organik gübre uygulamalarının patates çeşitlerinin verim ve kalite özellikleri üzerine etkileri önemli derecede farklılık göstermiştir. Çalışma sonucunda patates çeşitlerinin uygulanan organik gübrelere karşı tepkileri de farklılık arz etmektedir. Bu bulgular doğrultusunda çeşit ve gübre etkisinin oldukça önemli olduğu ve mutlaka birlikte değerlendirilmesi gerektiği görülmektedir. Elde edilen bulgulara göre tohumluk üretiminde doğru çeşit seçiminin oldukça önemli olmasının yanı sıra farklı yöntemlerle işlenmiş olan tavuk gübrelerinin organomineral gübre uygulamaları ile karşılaştırıldığında verim ve kalite değerleri üzerine etkilerinin benzer olduğu belirlenmiştir. $\mathrm{Bu}$ nedenle ekonomik açıdan değerlendirildiğinde tohumluk patates üretiminde organomineral gübrelerin yerine tavuk gübrelerinin taban gübresi olarak kullanılabilir olduğu sonucuna ulaşılmıştır.

\section{Kaynaklar}

Amanullah MM, Sekar S, Muthukrishnan P. 2010. Prospects and Potantial of Poultry Manure, Asian J.Plant Sci.,9(4), 172 -182 .

Anonim. 1998. Niğde Patates Araştırma enstitüsü Müdürlüğü yıllık araştırma raporları.

Anonim. 1999. Niğde Patates Araştırma enstitüsü Müdürlüğü yıllık araştırma raporları.

Anonim. 2008. Internal Disorders. Potato Education Guide. University of Nebraska. Lincoln. http://www.panhandle.unl.edu/potato/html/internal_ disorders.htm.

Arslan B, Kevseroğlu K. 1991. Bitki sıklığının bazı patates (Solanum tuberosum L.) çeşitlerinin verimi ve önemli özelliklerine etkileri. Yüzüncü Yıl Üniv. Ziraat Fak. Der. $1 / 3,89-111$.

Brady NC, Weil RR. 1996. The nature and properties of soils, 11th Edition, Prentice Hall International, Inc.

Chescheir PW, Westserman LM, Safley LM. 1986. Laboratory methods for estimating available nitrogen in manures and sludges", Agric. Wastes 18, 175-195

Christ P. 1986. The Infl uence of Within Row Spacing and Physiological Age on Yield of Potato with Special Reference to Stem Number. Potato Research, 29 (2):260.

Çalıskan CF. 1989. Değişik olumlu bazı patates çeşitlerinin fotoperiyodik-termik davranışları. Türkiye I. Patates Kongresi Tebliğleri. Ank. Ün. Ziraat Fak. Yayınları, 57-68. 
Çalışkan CF, İncekara F. 1984, Farklı dikim periyotlarının bazı erkenci ve geççi patates çeşitlerinde fizyoloji verim ve kaliteye etkisi. Ege Üniversitesi, Ziraat Fakültesi Dergisi, 21(2):77-88, İzmir.

Çalışkan CF, Yıldırım MB Çaylak Ö, Budak N, Yıldırım Z. 1997. Ana Ürün Olarak Dikimi Yapılan Değişik Olumlu Bazı Patates Çeşitlerinde Kısa Intervalli Dikim Periyotlarının Çeşitlerin Fizyoloji, Verim ve Kalite Üzerine Etkileri. Türkiye II. Tarla Bitkileri Kongresi 1997, 279-28, 222-25 Eylül, Samsun.

Çalışkan ME. 2001. Farklı Olgunlaşma Grubuna Giren Bazı Patates Çeşitlerinin Hatay Ekolojik Koşullarındaki Verim ve Kalite Özelliklerinin Belirlenmesi. MKU Ziraat Fakültesi Dergisi, 6: 39-50.

Didin M, Fenercioğlu H. 1999. Nevşehir-Niğde yöresinde yetiştirilen farklı patates çeşitlerinin bazı fiziksel ve kimyasal özelliklerinin belirlenmesi üzerinde bir araştırma. 2. Ulusal Patates Kongresi, 28-30 Haziran 1999. Atatürk Üniversitesi Oditoryumu, s.273-281, Erzurum.

Dikinya O, Mufwanzala N. 2010. Chicken manure-enhanced soil fertility and productivity: Effects of application rates, Journal of Soil Science and Environmental Management Vol. 1(3), pp. 46-54, 2010.

Edwards DR, Daniel TC. 1992. Environmental impacts of onfarm poultry waste disposal: A Review, Bioresource Technol. 41: 9-33

Ekin Z, Demir S, Oğuz F, Yıldırım B. 2013. Farklı Potasyum Dozlarında Arbusküler Mikorhizal Fungus (AMF) Uygulamalarının Patates (Solanum tuberosum L.)'in Yumru Verimi ve Yumru İriliği Dağılımı Üzerine Etkisi, YYÜ Tar Bil Derg (Yyu J Agr Sci)., 23(2):154-163

Eleroğlu H, Yıldırım A. 2011. Tavukçuluk Katı Atıklarının Tavuk Gübresine İşlenerek Çevre Kirliliğinin Azaltılması, 3. Ulusal Katı Atık Yönetimi Kongresi, Girne, 494-503.

Eleroğlu H, Yıldız S, Yıldırım A. 2013. Tavuk Dışkısının Çevre Sorunu Olmaktan Çıkarılmasında Uygulanan Yöntemler, Gaziosmanpaşa Bilimsel Araştırma Dergisi 2 (2013) 14-24.

Er C, Uranbey S. 1998. Nişasta Şeker Bitkileri. A.Ü. Ziraat Fak. Yay. Yayın No:1504, Ders Kitabı: 458, Ankara.

Esendal E. 1990. Nisasta ve Seker Bitkileri Cilt: 1 Patates, Ondokuz Mayıs Üniversitesi Ziraat Fakültesi Yayınları, Samsun.Fahem M, Haverkort AJ. 1988. Comparison of the growth of potato crops grown in Autumn and spring in north Africa. Pot. Res. 31(3) 557-568.

Genç A. 2006. Ekolojik Tarımda Kullanılabilecek Bazı Mineraller ve Bunların Mikoriza ve Kompost İle Aktive Edilmesi Üzerinde Bir Çalışma”, Çukurova Üniversitesi, Fen Bilimleri Enstitüsü, Toprak Anabilim Dalı, Yüksek Lisans Tezi

Güler A, Kolsarıcı Ö. 1995. Farklı lokasyonlarda yetiştirilen değişik olumlu bazı patates çeşitlerinde (Solanum tuberosum L.) yüksekliğin morfolojik fi zyolojik, verim ve kalite özelliklerine etkisi. Tr. J. Of Agriculture and Forestry, (19) 383-389.

Güler S, Acar M, Duran H, Aytaç S. 2011. Organik Patates Yetiştiriciliği Üzerinde Araştırmalar. Organik tarım Araştırma Sonuçları. T. C. Tarım ve Köyişleri Bakanlığı/Tarımsal Araştırmalar Genel Müdürlüğü, Ankara/Turkey, pp. 133-137.

Günel E. 1976. Erzurum ekolojik koşullarında farklı dikim ve hasat zamanlarının patates verimine ve bazı agronomik ve teknolojik karakterlerine etkisi üzerine bir araştırma. Atatürk Ü.Z.F. Tarla Bitkileri Bölümü, Erzurum.

Günel E, Oral E, Karadoğan T. 1991. Patatesin Bazı Agronomik ve Teknolojik Karakterleri Ararsındaki İlişsiler. Atatürk Üniv. Zir. Fak. Der. 22: 46-53.

Günel E, Karadoğan T. 1993. Effects of Different Irrigation Levels Applied at Different Growth Stages and Time of Ceasing Irrigation on Tuber Abnormalities of the Potatoes Grown under Ecological Conditions of Erzurum. Potato Research. 36: 391.
Günel E, Karadoğan T. 1992. Bazı stres şartlarının patatesin kalitesine etkisi. Yüzüncü Yıl Üni. Zir. Fak. Der., 2 : 125137.

Haverkort AJ, Van de Waart M, K.B.A., 1990. Bodlaender. Interrelationship of the number of initial sprouts, stemps, stolonos and tubers per potato plant. Potato Research, 33, 269-274.

Hsieh C, Hsieh CF, Hsu-KN. 1994. Effect of organic manures on the growth and yield of sweet pepper, Bulletin of Technique District Agric. Improv. Station, 42, 1-10, 1994.

Hutchinson CM. 2003. Potato Physiological Disorders-Growth Cracks. University of Florida. Extension. Institute of Food and Agricultural Sciences.

İncekara F, Çalışkan C. 1980. Farklı dikim periyotlarının bazı patates çeşitlerinde fi zyolojisi, verim ve kaliteye etkisi. Türkiye I. Patates Kongresi Tebliğleri, s.85-101. Ankara.

Kara E, Erel A. 1999. Tavuk gübresinin bazı toprak özelliklerine ve yulaf kuru bitki ağırlığına etkisi”, Anadolu, J. of AARI 9 (2), 91-104

Kara K. 2002. Erzurum Ekolojik Koşullarında Bazı Patates Çeşitlerinin Adaptasyonu ve Verimi üzerine Bir Araştırma. Anadolu J. Of AARI 12: 105-121, Mara.

Kara K, Günel E, Oral E. 1986. Erzurum Ekolojik Koşullarında Bazı Patates Çeşitlerinin Verim ve Adaptasyonu. Atatürk Üniv. Ziraat Fakültesi Dergisi, 17 (1-4): 53-67.

Karacapınar T. 2007. Iskarta (ebadı 28 mm'den küçük) yumruların farklı metodlarla yetiştirilmesi ve dikim sıklığının verim ve verim unsurları üzerine etkisi, Atatürk Üniversitesi Fen Bilimleri Enstitüsü, Yüksek Lisans Tezi, Erzurum.

Karadoğan T. 1995. Bazı Patates Çeşitlerinin Yumru Anormallikleri Üzerine Bir Araştırma. Atatürk Üniversitesi Ziraat Fakültesi Dergisi. Cilt: 26. Sayı: 2. S: 223.

Karadoğan T, Günel E. 1992. Bazı patates çeşitlerinin Erzurum ekolojik koşullarına adaptasyonu ile verim ve verim unsurları üzerine bir araştırma. Atatürk Üni. Zir. Fak. Der., 23: $1-15$.

Karadoğan T, Oral E. 1995. Değişik Azot Kaynaklarının Farklı Zamanlarda Uygulanmasinın Patatesin Bazı Kalite Özelliklerine Etkisi, Atatürk Ü. Zir. Fak. Der. 26 (1), 53-63, 1995

Karadoğan T. 1996. Azot ve fosforun uygulama şekli ve miktarının patatesin verim, verim unsurları ve kalitesine etkisi. Atatürk Üniv. Ziraat Fak. Derg., 27(1): 50-56.

Karadoğan T, Özer H, Oral E. 1997. Gübrelemenin patatesin bazı özellikleri üzerine etkisi. Atatürk Üniv. Ziraat Fak. Derg., 28(3): 441-453.

Karadoğan T, Özer H, Günel E. 1996. Effect of Nitrogen Source and Application Times on Potato Tuber Abnormalities. EAPR 13th Triennial Conference Abst. Venhoven, The Netherlands, p. 97-98.

Karaman S. 2006. Hayvansal Üretimden Kaynaklanan Çevre Sorunları ve Çözüm Olanakları, KSU. Journal of Science and Engineering 9(2), 133-139.

Koç T. 2002. Bandırma İlçesinde Tavukçuluğun Çevresel Etkisi, Ekoloji Dergisi, 11(43), 11-16.

Korkmaz A, Kızılkaya R, Horuz A, Sürücü A. 2000. Fan Separatörle Kurutulmuş Tavuk Gübresinde Azotun Bitkiye Yarayışlı Miktarının 15N İzleme Tekniğiyle Belirlenmesi”, Turk J Agric For, 24, 63-70

Korkmaz A, Sürücü A, Horuz A. 1996. Sulu Ham Tavuk Gübresinin Tarımda Organik Gübre Olarak Değerlendirilmesi”, OMÜ Ziraat Fakültesi Dergisi, 11(2), 117-125.

Kütük C, Topçuoğlu B. 1997. Etkinliği yönünden değişik organik gübreler ile amonyum nitratın 1spanak kalite ögeleri üzerindeki etkisinin karşılaştırılması", Akdeniz Üni. Ziraat Fak. Dergisi, 10: 70-80. 
Okur H. 2008. Pir öldürmenin patates (solanum tuberosum 1.) Çeşitlerinde verim kalite ve depolama özelliklerine etkileri, Gaziosmanpaşa Üniversitesi, Fen Bilimleri Enstitüsü, Yüksek Lisans Tezi, Tokat

Onaran H, Arıŏlu H. 1999. Niğde yöresinde yemeklik patates yetiştiriciliğinde, farklı yumru iriliklerine göre uygun bitki sıklı̆̆ının belirlenmesi. 2. Ulusal Patates Kongresi, 28- 30 Haziran, 284- 298, Erzurum.

Öztürk E, Polat T, Kavurmacı Z, Kara K. 2008. Bazı Patates (Solanum tuberosum L.) Çeşitlerinin Erzurum Koşullarında Yumru Verimi ve Verim Unsurlarının Belirlenmesi, Tarım Bilimleri Araştırma Dergisi 1 (1): 15-18.

Polat T, Öztürk E, Kavurmac1 Z, Kara K. 2008. Erzurum Ekolojik Kosullarinda Bazi Patates (Solanum tuberosum L.) Çesitlerinin Kalite Özelliklerinin Belirlenmesi, Alınteri 15 (B) 33-39

Reents HJ, Möller K, Tucher SV, Kainz M. 1998. Aspects of Cultivar Choice of Potatoes for Ecological Farming. Field Crops Abst. Vol: 51, No:10.

Samul I. 1982. A Rotation link: Rye as a winter Cover Crop Fallowed by potatoes as a second crop. 2. Effect of planting date and nitrogen application on yield and feeding value of three potato cultivars. Zesz. Nauk. ART Olszt. Rolnictwo. Nr., 33: 87-94.

Şahin K. 2003. Ahlat ilçesinde patatesin pazarlama yapısı üzerine bir araştırma. Y.Y.Ü. Zir. Fak. Derg. 13(2): 119125.

Şeker C, Ersoy İ. 2005. Degisik organik gübreler ve leonarditin toprak özellikleri ve mısır bitkisinin (Zea mays L.) gelişimi üzerine etkileri”, S.Ü. Ziraat Fak. Dergisi, 19 (35), 46-50.

Şenol S. 1970. Erzurum şartlarında bitki sıklığı ve tohum ağırlığının patateste verim ve diğer bazı özelliklerine etkisi. Ayyıldız matbaası, Ankara.
Taşkıran A, Esendal E. 1988. Farklı dikim zamanı ve değişik azot dozlarının Samsun' da çiftçi şartlarında, patatesin (Solanum tuberosum L.) yumru verimi ve bazı özelliklerine etkileri. Ondokuz Mayıs Üniv. Zir. Fak. Derg., 3(2):25-45.

Tugay ME, Coşkun A.Ş, Yı1maz G. 1999. Azotlu gübre miktarı ve verme zamanlarının patateste verim ve bazı özellikler üzerine etkileri. 2. Ulusal Patates Kongresi 28-30 Haziran 1999 G O Ü. Zir Fak.Samsun.655-658 .

Tunçtürk M, Tunçtürk R, Yıldırım B, Eryiğit T. 2004. Değişik Azot Dozları ve Sira Üzeri Mesafelerinin Patateste (Solanum Tuberosum L.) Verim ve Kalite Üzerine Etkileri. Yüzüncü Y1l Üniversitesi, Ziraat Fakültesi, Tarım Bilimleri Dergisi, 14(2), 95-104.

Ülger P. 1971. Erzurum ovasında patates ekim ve hasadında mekanizasyon imkanları üzerinde bir araştırma. Atatürk Üni. Zir. Fak. Yay. No: 133.

Yetilmezsoy K. 2010. Tavuk Çiftliklerinden Kaynaklanan Atıkların Yenilenebilir Enerji Kaynağı Olarak Değerlendirilmesi, IWES-2010, 2. Atık Teknolojileri Sempozyumu ve Sergisi, 132-136.

Yıldırım B, Tunçtürk M, Çiftçi C. 2005. Değişik Dikim Zamanlarının Farklı Patates (Solanum tuberosum L.) Çeşitlerinde Verim ve Verim Unsurları Üzerine Etkisi, Yüzüncü Y1l Üniversitesi, Ziraat Fakültesi, Tarım Bilimleri Dergisi (J. Agric. Sci.), 15(1): 1-9

Yılmaz G, 1993. Bazı Patates Genotiplerinde Çesit x Çevre Etkilesimleri. Gaziosmanpasa Üniversitesitesi Tarla Bitkileri Anabilimdal1, Doktora Tezi, (Danısman: Prof.Dr. M. Emin Tugay). Tokat.

Zamudio N, Neder R, Rojas E. 1986. The Influence of PreSprouting of Seed Tubers on Early Potato Production in Tucuman. Field Crop Abstracts. 39: 428.

Zengin M. 2007. Organik Tarım, Hasad Yayıncılık Ltd. Şti., İstanbul, 2007. 